\title{
Effect of In-Service Teacher Training Opportunities on Proactive Behavior of the Teachers at Higher Level
}

\author{
Dr. Quratulain Hina ${ }^{1}$, Dr. Saira Nudrat ${ }^{2}$
}

\begin{abstract}
To meet with the new challenges related to the teachers and teaching system, we need to develop an effective training system for the teachers. So keeping the situation in focus the research was designed to achieve the objective to compare the perception of male and female faculty members towards the teacher training opportunities and the employee's proactive behavior. Further to assess the effect of teacher training on proactive behavior of the teachers. The design of the study was descriptive. 11,092 teachers serving as the faculty members at higher level educational institutions were considered as the population of the study. Disproportionate stratified sampling technique was used to select the respondents for the purpose of data collection. 154 employees were selected as the sample of the study. The data was collected with the help of two sets of questionnaires designed to assess the in-service teacher training and proactive behavior (DV) of the respondents. The collected data was analyzed with the help of Statistical Package of Social Sciences 21 Edition. The $t$ test and regression analysis were used in the process of analysis. It was found that the there was no statistical difference between the male and the female employees regarding in-service training and proactive behavior. However in-service training had the significant effect on the development of proactive behavior of the employees as well. Further it was found out that the professional competence had the strongest effect on the development of proactive behavior. On the basis of findings it is recommended that training has to be linked with the daily routine problems and issues so that the employees may find it useful in their own situations.
\end{abstract}

Keywords: Teacher Training, In-Service Training, Proactive Behavior and Higher Education

\section{Introduction}

Teachers are known as the builders of a nation. In that perspective they have to deal with a responsible and sensitive position in any country. The civilized nations always pay respect to their teachers and empower the profession of teaching with all needed facilities to face the challenges of the every new day.

\footnotetext{
${ }^{1}$ Assistant Professor, Department of Education; National University of Modern Languages, Islamabad Email: quratulainhina@yahoo.com,

${ }^{2}$ Assistant Professor, Department of Education; National University of Modern Languages, Islamabad
} 
Teacher training programs are an example of such facilities. Training programs are very important in all the organizations. Institutions and organization use such teacher trainings to develop their human resource according to the current needs. Teaching as the most dynamic profession also needs the trained and skilled manpower to provide quality production. With every new day researches, concepts and theories are emerging and we need to equip our teachers with these new concepts and theories of learning. In order to do so teacher training programs are organized. There are two types of such trainings, one is pre service and the other is in service. Pre service is a part of job requirement to be attained before coming to the profession.

For the provision of the pre-service teacher education, there are a number of universities which are offering the courses related to B. Ed, M.Ed, BS. Ed etc. In Pakistan; at the time of the teacher selection at public sector for schools and colleges it is one of the requirements that the teacher must have completed the required pre service course. On the other hand in-service training is the helping tool provided by the management of the organization in order to keep the employees well equipped with the latest skills. Keeping in view the available resources and time every educational institution arranges to offer such in service training programs within their institutions. In this regard the higher education commission has developed a separate division that is solely responsible for the training of the faculty members during their service. This division is known as "learning innovation division" (LID).

LID is arranging continuous long and short term courses for the fresh faculty members to create a hub for the training. However higher level there is need for more efforts because the teachers at higher level are appointed by the universities according to their rules and regulation. Most of the time it is observed that highly qualified teachers with specified skills in their areas is not aware of the teaching skills and its complexities. So to train qualified teachers in the teaching field along with the in-service training is arranged by the Higher Education Commission (HEC) and periodically by the universities collectively. According to Kahn (1990) the In-service training gives you an opportunity to improve and develop your practical teaching, coaching, and counseling and/or management skills with the professional support of experts. The provision of in- service training is the job of the human development departments in the institution. Teacher training is equally important and essential for all the levels of education, however when it is related to the higher level of education it becomes more significant. The higher level education is an imperative stage that provides the skilled manpower for the different phases of life. The quality teaching at this stage directly affects the quality of manpower in the country. Developing countries need to provide special attention to this above mentioned areas in order 
to develop their skilled manpower. Thus the research is specially designed to assess the in-service teacher training opportunities provided to the teachers serving at the higher level of education. Further the researcher is also interested to check the effect of in-service teacher training opportunities on the development of proactive behavior of the teachers.

\subsection{Research Objectives}

The research was based on the achievement of the following objectives:

1. To compare the perception of male and female faculty members towards the teacher training opportunities.

2. To compare proactive behavior of the male and female faculty members.

3. To assess the effects of teacher training opportunities on proactive behavior of the teachers.

\subsection{Research Hypotheses}

1. There is no difference in the perception of male and female faculty members towards the teacher training opportunities.

2. There is no difference in the proactive behavior of the male and female faculty members.

3. There is a positive effect of teacher training on proactive behavior of the teachers.

\subsection{Significance of the Study}

The research has addressed the most important issue of the field of education. Teachers and their competence is the back bone of any education system. The quality of teachers is the assurance for the quality education. The teacher training system is a continuous need of the time. The world is changing with every new day and it is the professional responsibility of the teachers and the educational institution to upgrade their skills and competencies. Thus the teacher training programs need special focus at all levels of education. However at higher level it becomes more important. As the higher level education is the stage that produces the refined manpower for the country. Here the in- service training is needed to keep the system alive and able to meet the new challenges of the time. Thus the research would be significant as it will highlight the importance of such trainings. It would also help to understand the areas of these trainings that need to be focused by the organization in order to get desired results. Further it would let us know about the impact of such trainings on the behaviors of the teachers and the change in their proactive behavior. The study would suggest the improved way of planning these in- service training so that maximum results can be obtained. 


\section{Literature Review}

In every system of education, teacher is one of the substantial components. Excellence of plans, success of process executed, and surety of desired outcomes greatly depend on teacher. Teacher is in fact, operator of the teaching-learning process. Keeping in view this imperative role of a teacher in almost all of countries of the world, teachers are provided both pre-service and in-service training packages by educational management. These kinds of trainings equipped teachers with theoretical aspects of teaching profession and practical implications of the theory into the profession intelligently. Quality of education in the country lies mainly in the quality of teachers available (Iqbal, 1996). Self-efficacy of a teacher is reflected through their perceptions, actions, and behavior which serve like indicators for their performance in classroom situation (Bandura, 1994). In the words of Jerald (2007) people with higher level of self- efficacy incorporate their best ideas, show a realistic planning and establish a close connection with their students. Bockerts, Pitrich \& Zeidner (2000) deduced from their study that effective teaching strategies could only be implemented by effective and experienced teachers in class. Kazmi, Pervez and Mumtaz (2011) recommended the in- service teacher training as a condition for getting logical and innovative teachers in education system of Pakistan. Effective teacher training is unavoidable for producing a good teacher who is well-trained in respective domain and capable of achieving educational and organizational goals (Pintrich\& Schunk, 2002).

With reference to Pakistan, the need for a professional and trained teacher was realized first time in the report of National Commission on Education, in 1959 that quality in education can never be achieved without making teachers an essential component. Teacher education should be an integral and regular feature of the education system of Pakistan (NCE, 1959). The Pakistani system of education can only be flawless through resetting, and re-evaluating with critical approach (Education Policy 1972-80). For the sake of recruitment and selection of well-qualified and skillful teachers "education cadre" was suggested and along with that importance of selected teachers' regular in-service trainings was recommended by the National Education Policy 1992. Higher Education Commission (HEC) been proposing, offering and organizing number of teacher training programs aimed at various themes like development of classroom management skills, communication skills, and general behavioral aspects like intrinsic motivation of teachers, teacher-students relationship and assessment parameters in education. For the sake of training of teachers at higher education level, the department of learning innovations has been specifically directed by HEC to launch such kinds of platforms. More importantly three months 
residential teaching training program is being offered by Learning Innovation department (LI) since 2004. Similarly, Management Unit for System and Training (MUST) was also launched for this purpose by the University of Peshawar in 1985. In 1987, this institute was recognized and renamed as "Staff Training Institute" (STI). Main theme announced by the head of STI was to provide in-service training for a year to knowledge the teachers consisting largely on practical activities like knowledge delivery, assessment of students and computer competencies.

There is no homogeneity among teachers at all levels of institutes. They come up with their unique biographies to the class. In this perspective obviously they need to have different training during these jobs. Kahn (1990) reviewed teachers of university of Botswana and got to know about their opinion regarding teacher education provided. According to the data collected by the Kahn (1990) teachers discussed their concerns with problems like classroom control, lesson presentation, establishing targets for work, dealing with slow learners and coping with latest innovations in field of science and technology. On the other hand they pointed out major areas of in-service training such as lesson planning, setting of work schemes assessment of students and answering skills to questions in the class etc.

Duquette (1993) defined education as a combination of positive approach, mature reasoning, insight, immensity and professionalism. Providing firsthand knowledge in in- service teacher training programs is more effective way of quality education (Duffy, 1993). An experimental research was conducted by Sudanse and reported by Shommo (1995) aimed at development of critical thinking in Home Economics teachers. The purpose of the study was to modify and enable human behavior for resolving day to day issues with multiple approaches. Training focused on specific approaches for the sake of change in human values (Harber, 1987). It is an open fact nowadays that in teacher training programs practical strategies had magical effects for skill development and value establishment. In light of various studies, in-service training should focus on improving teacher's attitudes and styles rather than theoretical content of teacher education.

\subsection{Theoretical Framework}

The reflective practice has become a dominant paradigm in language teacher education research and programs worldwide. But it is not an innovation in teaching. It has its roots in the work of a number of educational theorists and practitioners. Most definitions on reflective thinking found in the literature of teacher education are based on Dewey's inquiry oriented concepts. In the 1980s, Dewey's foundational aspects on reflection were further extended by the American sociologist Donald A. Schön. Later on, in 1991 Michael J. Wallace 
described Schön's critique in a more explicit way (Wallace, 1991).

Wallace (1991) presented the "Reflective Model" for the in-service training of the teachers. It is a cyclical process. It is a continuous process that is interlinked with different elements. These elements are "Received knowledge, previous experiential knowledge, Practice, Reflection, Professional competence". This model is effective for pre service and in services both types of programs. However in the present research we have used it as a theoretical frame work for the assessment of in service teacher training. The base line of the model is the knowledge of the employees. This knowledge is divided into two parts. One is the received knowledge and the other is the previous experiential knowledge. It indicates the process of learning through assimilation and accommodation. The employees bring their own skills to the work place than certain skills they learn from their work environment. The both sources of knowledge develop a combine system of knowledge that leads to the practice and reflection. Practice is the application of learned knowledge and reflection is the further stage of practice that also includes understanding. All these things lead to the professional competence. Thus the same five elements were taken for the theoretical framework of the research and the tool was developed according the same five sections.

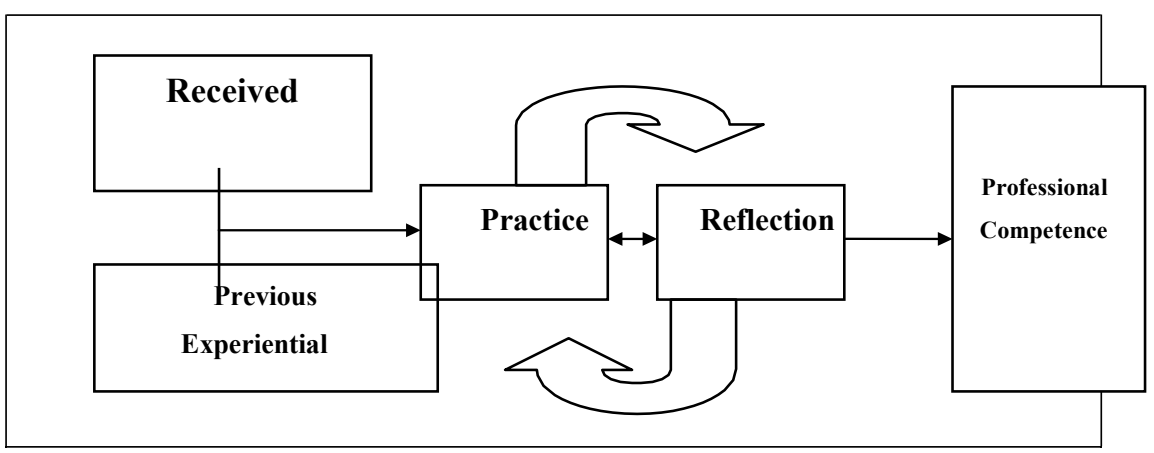

Fig. 1 Reflective Model by Wallace (1991)

\subsection{Operational Definitions}

\section{a. In service training}

In service training refers to the training program that is offered to the employees after joining the organization as an effort to train the employees related to their job skills. It focuses on development of job related skills, competencies and awareness related to the new technologies and researches in the field.

\section{b. Received Knowledge}

"Received knowledge is the vocabulary of the subject and the matching concepts, 
research findings, theories and skills which are widely accepted as being part of the necessary intellectual content of the profession" (Wallace, 1991).

\section{c. Previous experiential knowledge}

"The knowledge in action through practice of the profession is known as previous experiential knowledge" (Wallace, 1991).

\section{d. Practice}

"Implementation of the learned theories and skills is known as practice in reflective model" (Wallace, 1991).

\section{e. Reflection}

"Reflection is the feedback on the practice of profession as a way of developing expertise in it" (Wallace, 1991).

\section{f. Professional competence}

"The term, professional competencies, refers to all the knowledge, skills, and dispositions that teachers need to develop and master. It may also include the development of self-evaluation and self-improvement ability in professionals" (Wallace, 1991).

\section{g. Proactive behavior}

Proactive behavior refers to act before the activity. It is action in advance to control the situation. It is a result oriented behavior instead of waiting for the situation and adjusting according to it.

\subsection{Research Design}

\section{Research Methodology}

The research was based on the quantitative analysis approach. The research focused on the collection of data through questionnaires and its analysis with the help of statistical tests. By nature it was a survey based descriptive research.

\subsection{Population}

All the teachers serving at the higher level of education in Islamabad were considered as the population of the research. There were 11,092 faculty members serving in the different higher education institutions in Islamabad. Among which 7,640 were male and 3,452 were female employees.

\subsection{Sample}

By considering the male and female employees as the two major strata, disproportional stratified random sampling technique was selected to draw the sample for the research. 154 teachers were selected as the sample of the research. It was specially considered to maintain an almost equal number of male and female respondents to avoid gender biasness. Thus 75 respondents were male while 79 respondents were female faculty members.

\subsection{Instrument}

Two sets of questionnaires were used by the researcher in order to collect 
data. The questionnaire related to the independent variable (In-Service teacher training) was based on five sections related to the five sub variables related to the in-service teacher training. These sub variables were received knowledge, previous experiential knowledge, practice, reflection and professional competence. In total there were 25 items in the research questionnaire and it was rated on 5 point scale. To address the Dependent variable (Proactive Behavior) another questionnaire was developed that was based on 8 items.

\subsection{Data Collection}

The data was collected by the researcher personally and it was analyzed with the help of Statistical package of social sciences (SPSS). The t test and regression analysis were majorly used in order to analyze the data. Thus on the basis of the findings of the study the recommendation were suggested.

\section{Data Analysis}

\begin{tabular}{|c|c|c|}
\hline $\begin{array}{l}\text { Research } \\
\text { Objectives }\end{array}$ & $\begin{array}{l}\text { Research } \\
\text { Hypothesis }\end{array}$ & Analysis \\
\hline $\begin{array}{l}\text { To compare the } \\
\text { perception of male and } \\
\text { female faculty } \\
\text { members towards the } \\
\text { teacher training } \\
\text { opportunities. }\end{array}$ & $\begin{array}{l}\text { There is no difference in } \\
\text { the perception of male and } \\
\text { female faculty members } \\
\text { towards the teacher } \\
\text { training opportunities. }\end{array}$ & $\begin{array}{c}\text { Quantitative } \\
t \text { test }\end{array}$ \\
\hline $\begin{array}{l}\text { To compare proactive } \\
\text { behavior of the male } \\
\text { and female faculty } \\
\text { members. }\end{array}$ & $\begin{array}{l}\text { There is no difference in } \\
\text { the proactive behavior of } \\
\text { the male and female } \\
\text { faculty members. }\end{array}$ & $\begin{array}{c}\text { Quantitative } \\
\text { t test }\end{array}$ \\
\hline $\begin{array}{l}\text { To assess the effect of } \\
\text { teacher training } \\
\text { opportunities on } \\
\text { proactive behavior of } \\
\text { the teachers. }\end{array}$ & $\begin{array}{l}\text { There is a positive effect } \\
\text { of teacher training on } \\
\text { proactive behavior of the } \\
\text { teachers. }\end{array}$ & $\begin{array}{l}\text { Quantitative } \\
\text { Regression }\end{array}$ \\
\hline
\end{tabular}

\subsection{Findings/ Results}

Table No 4.1

Cronbach's Alpha Reliability of the Scales

\begin{tabular}{ccc}
\hline Scales & N of items & Cronbach's Alpha \\
\hline In-Service Training & 25 & .87 \\
Assessment & & .82 \\
Proactive Behavior & 8 & \\
\hline
\end{tabular}


It has been found from the Table No. 4.1 that the Cronbach's Alpha reliability of the In-Service training assessment scale was .87 and the Cronbach's Alpha reliability of the scale developed to assess proactive behavior was .82 . That shows that the both scales were reliable and can be used in the future researches with a fair amount of confidence.

Table 4.2

Correlation between In-Service Training Assessment Scale and Proactive Behavior

\begin{tabular}{cccc}
\hline Scale & $\begin{array}{c}\text { In-Service } \\
\text { Training } \\
\text { Assessment }\end{array}$ & Proactive Behavior & Total \\
\hline $\begin{array}{c}\text { In-Service } \\
\text { Training }\end{array}$ & 1 & $.174^{*}$ & $.935^{* *}$ \\
$\begin{array}{c}\text { Assessment } \\
\text { Proactive } \\
\text { Behavior } \\
\text { Total }\end{array}$ & $.174^{*}$ & 1 & $.513^{*}$ \\
\hline
\end{tabular}

*. Correlation is significant at the 0.05 level (2-tailed).

**. Correlation is significant at the 0.01 level (2-tailed).

Table 4.2 shows that the both scales were correlated at 0.05 level of significance as well.

Table No. 4.3

Comparison between male and female employees ( $\mathrm{t}$ test)

\begin{tabular}{llccccc}
\hline Variable & & $\mathrm{N}$ & Mean & $\mathrm{t}$ value & Df & Sig. \\
\hline Received Knowledge & Male & 75 & 17.56 & 1.54 & 152 & .12 \\
& Female & 79 & 16.59 & & & \\
\hline Variable & & $\mathrm{N}$ & Mean & $\mathrm{t}$ value & $\mathrm{Df}$ & Sig. \\
\hline $\begin{array}{l}\text { Experiential } \\
\text { Knowledge }\end{array}$ & Male & 75 & 13.16 & -.38 & 152 & .70 \\
& Female & 79 & 13.37 & & & \\
\hline Variable & & $\mathrm{N}$ & Mean & $\mathrm{t}$ value & Df & Sig. \\
\hline Practice & Male & 75 & 15.85 & .24 & 152 & .80 \\
& Female & 79 & 15.73 & & & \\
\hline
\end{tabular}


Volume I- Issue I (June 2015)

\begin{tabular}{lllllll}
\hline Variable & & $\mathrm{N}$ & Mean & $\mathrm{t}$ value & $\mathrm{Df}$ & Sig. \\
\hline Reflection & Male & 75 & 22.15 & -.83 & 152 & .40
\end{tabular}

\begin{tabular}{lllllll} 
& Female & 79 & 22.65 & & & \\
\hline Variable & & $\mathrm{N}$ & Mean & t value & Df & Sig. \\
\hline $\begin{array}{l}\text { Professional } \\
\text { Competence }\end{array}$ & Male & 75 & 24.57 & -.67 & 152 & .50 \\
& & & & & & \\
\hline
\end{tabular}

$* \mathrm{P}<0.05 * * \mathrm{P}<0.01$

Table No 4.4

Comparison between male and female employees ( $t$ test)

\begin{tabular}{|c|c|c|c|c|c|c|c|}
\hline Variable & & & $\mathrm{N}$ & Mean & t value & Df & Sig. \\
\hline \multirow{2}{*}{$\begin{array}{l}\text { In-Service } \\
\text { Assessment }\end{array}$} & Training & Male & 75 & 93.29 & -.02 & 152 & .98 \\
\hline & & Female & 79 & 93.34 & & & \\
\hline
\end{tabular}

$$
* \mathrm{P}<0.05 * * \mathrm{P}<0.01
$$

Table No. 3 and 4 revealed that there was statistically no significant difference between male and female respondents with reference to all five sub variables (Received Knowledge, Experiential Knowledge, Practice, Reflection and Professional Competence) of in-service training assessment. Thus it proves that the male and the female respondents were equally responding towards the opportunities available for in-service training. Thus the hypothesis "There is no difference in the perception of male and female faculty members towards the teacher training opportunities" is approved.

Table No. 4.5

Comparison between male and female employees ( $\mathrm{t}$ test)

\begin{tabular}{llccccc}
\hline Variable & & $\mathrm{N}$ & Mean & $\mathrm{t}$ value & Df & Sig. \\
\hline Proactive Behavior & Male & 75 & 28.33 & -.21 & 152 & .83 \\
& Female & 79 & 28.52 & & & \\
\hline
\end{tabular}

$$
* \mathrm{P}<0.05 * * \mathrm{P}<0.01
$$

Similarly the proactive behavior (Table 4.5) of the male and female respondents was also same and there was no significant difference $(t=-.21)$ 
between them in this regard. So in that case the hypothesis "There is no difference in the proactive behavior of the male and female faculty members" is approved as well.

Table No 4.6

Effect of In-Service Training on Proactive Behavior (Regression Analysis)

\begin{tabular}{lccccc}
\hline $\begin{array}{c}\text { Independent } \\
\text { Variable }\end{array}$ & $\begin{array}{c}\text { Dependent } \\
\text { Variable }\end{array}$ & $\begin{array}{c}\beta \\
\text { Coefficient }\end{array}$ & t-value & Sig & R Square \\
\hline $\begin{array}{l}\text { In-Service } \\
\text { Training }\end{array}$ & $\begin{array}{c}\text { Proactive } \\
\text { Behavior }\end{array}$ & .174 & 2.182 & .03 & .03 \\
Assessment & & & & & \\
\hline
\end{tabular}

The Table 4.6 represents that the $\mathrm{R}^{2}$ value is 0.03 . It explains that the independent variable (In-Service Training) describes 03 percent variation in developing the proactive behavior. The rest is due to other factors. While the coefficient $(B=.174)$ was significant at 0.05 level. It indicates that in-service training and proactive behavior are positively related with each other. Thus the hypothesis "There is a positive relationship between teacher training and proactive behavior of the teachers" is approved.

Table No 4.7

Relationship between In-Service Training and Proactive Behavior (Regression Analysis)

Model

Standardized
Coefficients

$\begin{array}{lll}\mathrm{T} & \mathrm{Si} & \mathrm{R} \\ & \mathrm{g} . & \text { Square }\end{array}$

\begin{tabular}{|c|c|c|c|c|c|}
\hline Independent & Dependant & Beta & & & \\
\hline Variable & Variable & & & & \\
\hline Received & Proactive & .141 & 1.75 & .08 & .020 \\
\hline knowledge & Behavior & & & & \\
\hline Experiential & & & & & \\
\hline knowledge & & .075 & .93 & .35 & .006 \\
\hline \multicolumn{6}{|l|}{ Practice } \\
\hline & & .096 & 1.19 & .23 & .009 \\
\hline Reflection & & .103 & 1.27 & .20 & .011 \\
\hline $\begin{array}{l}\text { Professional } \\
\text { competence }\end{array}$ & & .204 & 2.56 & .01 & .042 \\
\hline
\end{tabular}

Knowledge, Experiential Knowledge, Practice, Reflection and Professional Competence) were having different levels of effect on the dependant variable (Proactive Behavior). 
1. $\mathrm{R}^{2}$ value (0.02) explains that the received knowledge (independent sub variable) describes 02 percent variation in proactive behavior. The rest is due to other factors. The value of $p=.08>0.05$, which means that there is no significant effect. (Table No. 7).

2. $\mathrm{R}^{2}$ value (0.006) explains that the experiential knowledge (independent sub variable) describes only 0.6 percent variation in proactive behavior. It explains No Variation, because the effect is not significant (Table No. 7).

3. $\mathrm{R}^{2}$ value (0.009) explains that the practice (independent sub variable) describes only 0.9 percent variation in proactive behavior. It shows No Variation, because the effect is not significant (Table No. 7).

4. $\mathrm{R}^{2}$ value (0.011) explains that the reflection (independent sub variable) describes only 1.1 percent variation in proactive behavior. It describes No Variation, because the effect is not significant (Table No. 7).

5. $\mathrm{R}^{2}$ value (0.042) explains that the professional competence (independent sub variable) describes only 4.2 percent variation in proactive behavior. The rest is due to other factors. While the coefficient $(B=.204)$ was significant at 0.01 level (Table No. 7).

Thus it shows that Received Knowledge, Experiential Knowledge, Practice and Reflection were not having any statistically significant effect on the development of proactive behavior of the employees, while Professional Competence was found having 4.2 percent effect on proactive behavior and it was statistically significant at 0.01 level.

\section{Discussion}

In service teacher training is the most important aspect of the teaching profession. However, opportunities to train the teachers according to the current needs are inadequate and insufficient (Britt, Irwin \& Ritchie, 2001; Ottevanger, Macfarlane \& Clegg, 2005). Further there is a gap between the theory and the practice (Krainer, 1999; Even, 1999). According to Krainer, 1999; Even, 1999 "teacher training programs are facing a number of challenges such as less resources, unavailability of trained trainers, lack of serious attitude and inadequate feedback channels". However all these issues can be solved with proper planning. Keeping in view the fact that such training programs can reflect in the better performance of the teachers in future, there is a need to adopt quick and valid measures to organize and improve teacher training all over the country. Thus the current research also focused the same area. The study focused the three major objectives.

The first objective was "To compare the perception of male and female faculty members towards the teacher training opportunities". The research findings revealed no significant difference between male and female respondents with reference to the teacher training. Similarly in response to the second 
research objective "To compare proactive behavior of the male and female faculty members", no statistically significant difference was found between proactive behavior of male and female teachers. While "To assess the effect of teacher training opportunities on proactive behavior of the teachers" regression analysis was used and it was found that in- service training effects the development of proactive behavior of the employees up to 3 percent only. While professional competency was the strongest variable that was responsible to affect the proactive behavior of the employees. Thus it is also worth mentioning that the future researchers may lead the research in the direction to find out the other factors that are affecting the proactive behavior of the employees.

\section{Recommendations}

1. In the light of the findings/ results of the research it is recommended that the male and female employees serving as the faculty members at the higher level of education in Pakistan may have the equal opportunities related to the in-service training. As the results show that there was no difference between male and female respondents towards the Received Knowledge, Experiential Knowledge, Practice, Reflection and Professional Competence. Similarly the proactive behavior of the both genders was also same.

2. As the results revealed that in-service training and the proactive behavior of the employees was found positively related with each other. Thus it is worth to recommend that there is a need to pay special attention to the arrangement of in-service training programs frequently. Such programs can be of short duration but it has to be link with the current needed job related skills. It has also to be ensured that each and every employee has to get an equal chance of participating in such trainings.

3. It is suggested that the different higher level institutions and universities can join their hand to organize teacher in-service training programs according to the available human resources and skills. In this way there would be a chance of the sharing of knowledge and skills between the universities.

4. University management needs to pay attention to the professional competence of the employees. In order to learn new methods and techniques related to the field of teaching on line workshops and video conferences can also be arranged.

5. In-service training has to be linked with the performance benefits and promotions to attract the employees to take part in such activities. 
6. It is recommended that training has to be linked with the daily routine problems and issues so that the employees may find it useful in their own situations.

7. As a part of recommendations a model has been suggested by the researcher to regulate the teacher training program at university level. The model suggests focusing on the following basic teacher training areas (Fig. 2).Further the model also provides the explanation of the process of training programs (Fig. 3). The suggested process is based on the six steps with the purpose that each cycle of the training will focus on the one selected area of training need.

\section{Teacher Training Areas}

\section{KNOWLEDGE DEMANDS}
a. Awareness of self and surroundings
b. Subject knowledge with specialization
c. Understanding professional requirements
d. Good perception of social and moral values
e. Understanding students potentials and needs

SKILL DEMANDS
a.
Learning art of teaching
b. Designing interactive activities
c. Learning teaching methods and strategies
d. Measuring learning achievement

PLANNING DEMANDS
a. Learning course planning
b. Learning sessions planning
c. Learning academic planning
d. Learning assessment planning

MANAGEMENT DEMANDS

a. Learning administrative skills 

b.
Learning management skills
c. Learning official correspondence
d. learning record keeping skills

RESEARCH DEMANDS
a.
Planning research
b.
Conducting research
c. Supervising research
d. Report writing
e. Paper Writing

PERSONAL DEMANDS
a. Respect for administrative hierarchy
b. Cooperation with individuals and groups
c. Developing acceptable behavior
d. Respect for others ideas and care
e. Following the ethical codes
f. Positive social interaction 
L

Fig. No. 2 Teacher Training Areas

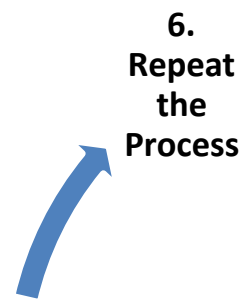

5.

Evaluate

Training

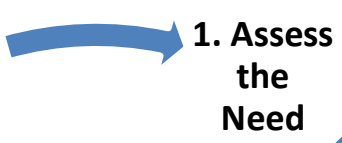

4.

Conduct

Training

Need

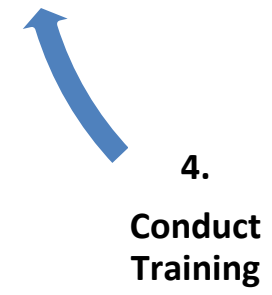

Fig No. 3 Process of Training 


\section{References}

Bandura, A. (1994). Self-efficacy. V. S. Ramachaudran (Ed.), Encyclopedia of human behavior (Vol.4, pp. 71-81). New York: Academic Press.

Bockerts, M., Pitrich, p., \& Zeidner, M. (2000). Handbook of self-regulation. San Diego: Academic press.

Britt, M. S., Irwin, K. C. \& Ritchie, G. (2001). Professional conversations and professional growth. Journal of Mathematics Teacher Education, 4(1), 2943.

Duffy, A. (1993). Steps towards new horizons. International Journal of Early Childhood, 25(1): 49-53.

Duquette,C.(1993). A School-Based Teacher Education Program: Perceptions and Attitudes. Journal of Educational Research, 39(4), 419-32.

Even, R. (1999). The development of teacher leaders and in-service teacher educators. Journal of Mathematics Teacher Education, 2(1), 3-24.

Govt of Pakistan (1959). National Commission on Education 1959. Ministry of Education, p-265

Govt of Pakistan (1972). The Education policy 1972-80. Islamabad: Ministry of Education, p-23

Govt of Pakistan (1979). National Education Policy and Implementation Programme 1979. Islamabad: Ministry of Education, p-16

Govt of Pakistan (1992). National Education Policy 1992-2002. Islamabad: Ministry of Education. pp.26-62

Harber, C. (1987). The West Midlands-West Africa Project. British Journal of In-Service Education, 13(2): 86-90.

Iqbal, M. Z. (1996). Teachers Training: The Islamic perspective. Islamabad: Institute of Policy Studies, p-107 